\title{
Seasonal ice-speed variations in 10 marine- terminating outlet glaciers along the coast of Prudhoe Land, northwestern Greenland
}

\section{Paper}

Cite this article: Sakakibara D, Sugiyama S (2020). Seasonal ice-speed variations in 10 marine-terminating outlet glaciers along the coast of Prudhoe Land, northwestern Greenland. Journal of Glaciology 66(255), 25-34. https://doi.org/10.1017/jog.2019.81

Received: 18 April 2019

Revised: 14 October 2019

Accepted: 14 October 2019

First published online: 13 November 2019

Key words:

Arctic glaciology; glacier monitoring; ice velocity; remote sensing

\section{Author for correspondence:}

Daiki Sakakibara, E-mail: sakakibara@pop. lowtem.hokudai.ac.jp (c) The Author(s) 2019. This is an Open Access article, distributed under the terms of the Creative Commons Attribution licence (http:// creativecommons.org/licenses/by/4.0/), which permits unrestricted re-use, distribution, and reproduction in any medium, provided the original work is properly cited.
Daiki Sakakibara $^{1,2}$ and Shin Sugiyama ${ }^{2,1}(\mathbb{D}$

${ }^{1}$ Arctic Research Center, Hokkaido University, Kita-21, Nishi-11, Kita-ku, Sapporo, 001-0021, Japan and ${ }^{2}$ Institute of Low Temperature Science, Hokkaido University, Kita-19, Nishi-8, Kita-ku, Sapporo, 060-0819, Japan

\section{Abstract}

We present a 3-year record of seasonal variations in ice speed and frontal ablation of 10 marineterminating outlet glaciers along the coast of Prudhoe Land in northwestern Greenland. The glaciers showed seasonal speedup initiated between late May and early June, and terminated between late June and early July. Ice speed subsequently decreased from July to September. The timing of the speedup coincided with the onset of the air temperature rise to above freezing, suggesting an influence of meltwater availability on the glacier dynamics. No clear relationship was found between the speedup and the terminus position or the sea-ice/ice-mélange conditions. These results suggest that the meltwater input to the glacier bed triggered the summer speedup. The excess of summer speed (June-August) over the mean for the rest of the year accounted for $0.5-13 \%$ of the annual ice motion. Several glaciers showed seasonal frontal variations, i.e. retreat in summer and advance in winter. This was not due to ice-speed variations, but was driven by seasonal variations in frontal ablation. The results demonstrate the dominant effect of glacier surface melting on the seasonal speedup, and the importance of seasonal speed patterns on longer-term ice motion of marine-terminating outlet glaciers in Greenland.

\section{Introduction}

Mass loss from the Greenland ice sheet has contributed to global sea level rise at a mean rate of $0.47 \mathrm{~mm} \mathrm{a}^{-1}$ during the period from 1991 to 2015 (van den Broeke and others, 2016). Since $\sim 40 \%$ of the mass loss was due to changes in ice discharge from marine-terminating outlet glaciers (van den Broeke and others, 2016), a future projection of ice discharge from the Greenland ice sheet is crucial for understanding the magnitude and timing of global sea level rise. Ice discharge from the ice sheet is dependent on the ice speed of marine-terminating outlet glaciers. Glaciers in Greenland had accelerated substantially in the early 2000s, and ice speed has been kept at the accelerated level since 2005 (e.g. Howat and others, 2008; Moon and others, 2012; King and others, 2018; Mankoff and others, 2019). Observed speed changes are inhomogeneous in space and time; thus further investigations and insights are needed to project future changes in marine-terminating outlet glaciers in view of our changing climate.

Recent progress in satellite remote sensing techniques contributes to the studies of seasonal speed patterns of marine-terminating glaciers in Greenland (Howat and others, 2010; Moon and others, 2014, 2015; Vijay and others, 2019). Reported data indicate significant summer acceleration, suggesting the importance of high-frequency ice-speed measurements to the quantification of annual ice discharge. Sole and others (2011) reported the $\sim 1 \%$ contribution of summer speedup to annual ice motion of a marine-terminating outlet glacier in southwest Greenland. However, as the study site was far inland from the glacier terminus at $>1200 \mathrm{~m}$ a.s.l., the importance of summer speedup to glacier dynamics in the vicinity of the terminus remains poorly understood.

Seasonal speed variations are essential also for understanding the response of ice dynamics to external forcings (Howat and others, 2010; Carr and others, 2013; Moon and others, 2014; Lemos and others, 2018; Vijay and others, 2019). Moon and others (2014) reported the seasonal speed patterns of 55 marine-terminating glaciers along the coast of northwest, west, southeast and southwest Greenland. This study classifies seasonal speed patterns into three types, depending on their sensitivity to the terminus position, meltwater production and the subglacial hydrological system. Seasonal speed patterns in northwestern Greenland were correlated with meltwater production, suggesting a higher sensitivity of the glacier dynamics in this region to climate variability (Moon and others, 2014). More recently, higher frequency ice-speed measurements were performed on 45 glaciers over broader areas in Greenland (Vijay and others, 2019). This study shows the concurrence of summer speedup and the onset of glacier surface melting, which essentially agrees with the conclusion by Moon and others (2014). These studies indicate the importance of expanding the spatial and temporal coverage of these data to include the investigation of future responses of Greenlandic outlet glaciers to changing climate.

Seasonal speed variations in marine-terminating glaciers are influenced by several factors such as subglacial hydraulic conditions, surface melting and drainage into the glacier bed, terminus variations and sea-ice/ice-mélange conditions (e.g. Howat and others, 2010; Carr and 
others, 2013; Moon and others, 2014; Pimentel and others, 2017). Numerical modeling and observational studies indicate the importance of the glacier terminus position in ice dynamics (Howat and others, 2008; Joughin and others, 2008a, 2008b; Nick and others, 2009). Observations in southeast Greenland have shown that resistive stress acting on the terminus is diminished when a marine-terminating glacier retreats, a process which is significant enough to cause flow acceleration (Howat and others, 2008). Numerical experiments on Helheim Glacier confirmed the critical effect on glacier dynamics of bed geometry near the terminus (Nick and others, 2009). Sea ice and ice mélange in front of a marine-terminating glacier are thought to have a buttressing effect on the glacier front (Joughin and others, 2008a; Amundson and others, 2010). Therefore, the melting of sea ice and ice mélange has the potential to reduce resistive stress acting on the glacier and cause summer speedup. The meltwater input to the glacier bed and the evolution of a subglacial drainage system also influence seasonal speed variations (Joughin and others, 2008b; Schoof, 2010; Sole and others, 2011). In early summer, surface melt increases and water drains to the bed, where a subglacial drainage system is not sufficiently developed. In such a situation, subglacial water pressure increases and basal sliding is enhanced. The drainage system develops further as a greater amount of meltwater drains, resulting in a drop in subglacial water pressure and a decrease in ice speed (e.g. Bartholomew and others, 2010; Sundal and others, 2011). These mechanisms have been proposed and tested at some of the glaciers in Greenland, but processes affecting seasonal speed variations are not yet fully understood.

To investigate seasonal speed variations of marine-terminating outlet glaciers, we processed satellite images for high-frequency ice-speed variations in 10 marine-terminating outlet glaciers along the coast of the Prudhoe Land, northwestern Greenland. We compared observed ice-speed changes in years 2014, 2015 and 2016 with the terminus position, sea-ice/ice-mélange conditions and air temperature in order to discover the source of seasonal speed variations. The contribution of summer speedup to annual ice motion was quantified to evaluate its importance to ice discharge from the glaciers. We also computed seasonal variations in frontal ablation, by comparing the ice speed and terminus positions obtained in this study.

\section{Study site}

We focused on 10 marine-terminating outlet glaciers located along the coast of Prudhoe Land in northwestern Greenland $\left(77.53-77.94^{\circ} \mathrm{N}\right.$ and $66.04-71.63^{\circ} \mathrm{W}$ ) (Fig. 1). This area has been a central part of previous studies on the dynamics of outlet glaciers (Porter and others, 2014; Sugiyama and others, 2015; Tsutaki and others, 2016; Sakakibara and Sugiyama, 2018), but not covered by past studies of seasonal speed variations (Moon and others, 2014, 2015; Vijay and others, 2019). A number of outlet glaciers, having a front width between $1.5 \mathrm{~km}$ (Sharp Glacier) and $5.0 \mathrm{~km}$ (Tracy Glacier), are located within a relatively small area. Glaciers in the study area have been retreating since the early 2000s and some of the glaciers have shown significant acceleration during this period (Sakakibara and Sugiyama, 2018).

Heilprin and Tracy Glaciers are the two largest glaciers in this region, having a drainage basin of $1.04 \times 10^{4} \mathrm{~km}^{2}$ in total (Rignot and Kanagaratnam, 2006). Tracy Glacier retreated at a rate of $200 \mathrm{~m} \mathrm{a}^{-1}$ and accelerated from 810 to $1740 \mathrm{~m} \mathrm{a}^{-1}$ during the period from 1980s to 2014 (Sakakibara and Sugiyama, 2018), which was the greatest change recorded among the study glaciers. Farquhar, Melville and Sharp Glaciers flow at a rate more than $400 \mathrm{~m} \mathrm{a}^{-1}$ (Sakakibara and Sugiyama, 2018). These five glaciers are located in the eastern half of the study area, draining into a $\sim 20 \mathrm{~km}$ wide fjord Inglefield Bredning. Hubbard, Bowdoin, Verhoeff, Morris Jesup and Diebitsch Glaciers are located in the western half of the study area, where each individual fjord connects to western part of Inglefield Bredning or directly to northern Baffin Bay. The ice speed near the termini of these glaciers ranges from 90 to $400 \mathrm{~m} \mathrm{a}^{-1}$ (Sakakibara and Sugiyama, 2018), which is smaller than the speed of the glaciers in the eastern half. Heilprin, Farquhar, Bowdoin and Diebitsch Glaciers showed a substantial speedup and retreated rapidly after 2000 (Sakakibara and Sugiyama, 2018).

\section{Data and methods}

To measure the glacier terminus position, ice speed and sea-ice/ ice-mélange conditions from 2014 to 2016, we used satellite images of the Landsat 8 Operational Land Imager (OLI) (level $1 \mathrm{~T}$, with $15 / 30 \mathrm{~m}$ resolutions) distributed by the United States Geological Survey. Because the OLI is an optical sensor, the measurements were performed when sunlight was available between March and October.

We obtained hourly air temperatures at Mittarfik Qaanaaq (Qaanaaq Airport; $77.48^{\circ} \mathrm{N}, 69.38^{\circ} \mathrm{W} ; 16 \mathrm{~m}$ a.s.l.) located within $30-84 \mathrm{~km}$ of the glacier termini, from the National Oceanic and Atmospheric Administration. The temperature dataset was utilized to calculate mean air temperature during a period for each ice-speed measurement. The Qaanaaq temperature showed a good correlation $\left(r^{2}=0.94, p<0.001\right)$ with that recorded at Thule Airbase located $108 \mathrm{~km}$ south from Qaanaaq. Thus, we assume the data well represent air temperature over the study area.

\subsection{Ice speed}

The ice speed was measured by automatically tracking glacier surface features on temporally separated satellite-image pairs (Scambos and others, 1992; Sakakibara and Sugiyama, 2014, 2018). We used Landsat 8 OLI images obtained from 2014 to 2016 for this purpose. These images were acquired with temporal separations of 16-48 days and study glaciers were covered by multiple tracks, thus enabling high-frequency speed measurements to be made. The frequency of the ice-speed measurement at each glacier was 44-196 times per year, depending on the availability of the scene. Glacier surface displacement was measured with an automatic image matching scheme known as the orientation correlation method in the frequency domain (CCF-O) (Heid and Kääb, 2012). The correlation window size was 30 pixels, and the Landsat images were co-registered using displacement vectors obtained in off-ice areas. Measurements were taken over areas near the glacier termini, and we sampled speed at the glacier center at a distance of $0.7-2.4 \mathrm{~km}$ from the termini in 2014 . The distance from the terminus to the sampling site for each glacier was approximately equal to the half of the glacier front width (Moon and others, 2014). The magnitude of summer speedup was dependent on the distance from the glacier front, but the timing of the peak speed and seasonal patterns was not influenced by the sampling location. Displacement vectors obtained with a low signal-to-noise ratio $(<30)$ were excluded, and remaining vectors were filtered using directional and median low-pass filters (Sakakibara and Sugiyama, 2014). Ice-speed data at the sampled locations were smoothed by taking the median values of 7 by 7 neighboring pixels (Howat and others, 2010). Ambiguities due to the uncertainty in the cross-correlation peak and co-registration errors ranged from 6 to $300 \mathrm{~m} \mathrm{a}^{-1}$ with a mean value of $43 \mathrm{~m} \mathrm{a}^{-1}$, depending on image quality and length of temporal separation. After the filtering and smoothing procedures, measurement error was mostly associated with the co-registration 


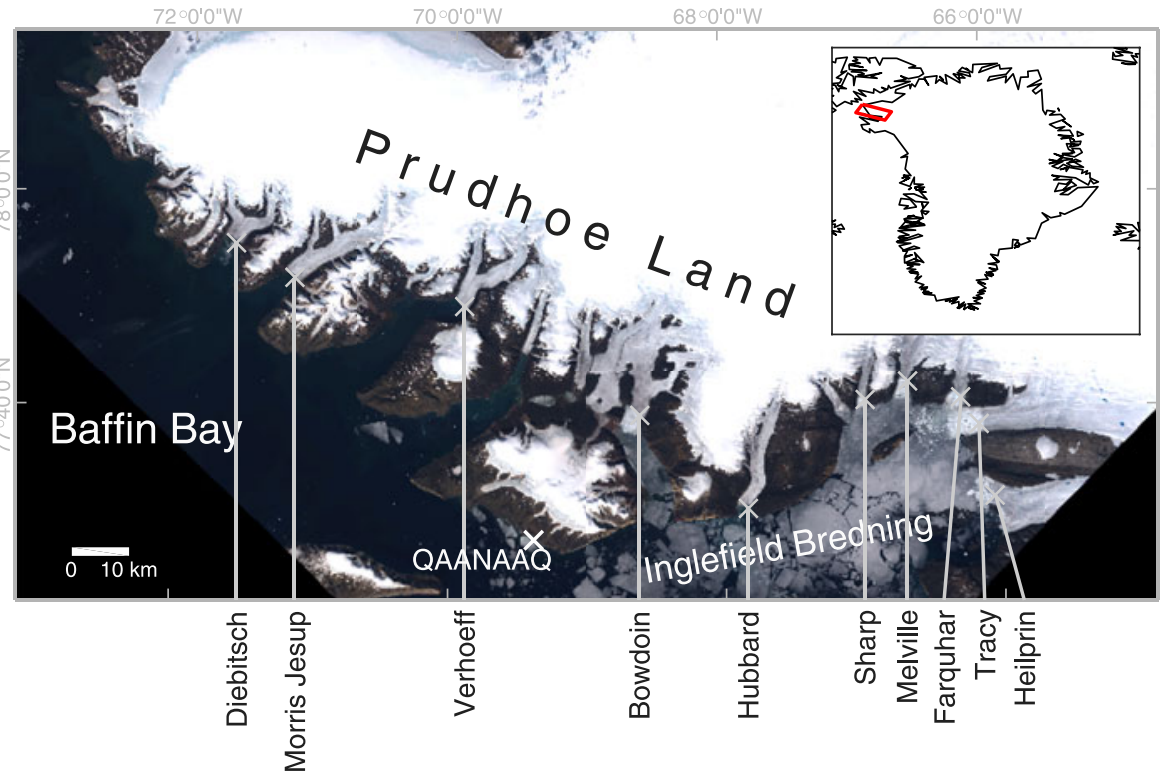

Fig. 1. The locations of the study glaciers along the coast of Prudhoe Land. The background is a true color mosaic Landsat image acquired on 9 July 2014. The inset shows the location of the study area in Greenland. of image pairs. Thus, the uncertainty was not influenced by seasonal changes in glacier surface conditions.

\subsection{Terminus position and sea-ice/ice-mélange conditions}

Glacier terminus positions were mapped from 2014 to 2016, using false color composite images generated by assigning the colors blue, green and red to bands 4, 5 and 6 of the Landsat 8 images, respectively (McNabb and Hock, 2014). Relatively coarse false color composite images were used for this purpose because the boundary between a glacier terminus and sea ice was more clearly observed than panchromatic images available in a higher resolution. In each image, the glacier frontal margins were delineated manually using the QGIS geographic information system software. Mean displacement of the terminus position was computed by dividing the areal change near the frontal margin by the width of the terminus (Moon and Joughin, 2008). Relative positioning errors introduced during the process of overlapping the Landsat 8 images was $\pm 8 \mathrm{~m}$ (Sakakibara and Sugiyama, 2018). This value was derived as the co-registration error in the ice-speed measurement, by computing the root-mean-square of displacement obtained in off-ice areas.

Sea ice and ice mélange conditions near the termini were determined using a method proposed by Moon and others (2015). In every image, sea-ice/ice-mélange concentration and potential rigidity within $\sim 5 \mathrm{~km}$ from each glacier terminus were classified as likely to be rigid (rigid), potentially rigid (mixed) or unlikely rigid (open) (Moon and others, 2015) (example is shown in Fig. 2). The condition was classified as 'rigid' when the region in front of the glacier was completely or nearcompletely covered by sea ice/ice mélange. An 'open' classification was given for open water. When the region was covered with a substantial amount of ice but also with open water, the condition was classified as 'mixed' (Moon and others, 2015).

\subsection{Frontal ablation}

Frontal ablation (sum of calving and subaqueous melting) was calculated by subtracting the terminus displacement from ice motion over a period from March 2014 to September 2016. Mean ice speed across the glacier was estimated as $55-90 \%$ (mean: $73 \%$ ) of the speed obtained at the sampling site at the glacier center. The conversion factor was derived for each glacier by computing a mean speed across the glacier using all available measurements. We assume ice speed was uniformly distributed from the surface to the bottom (perfect sliding). Uncertainty in the calculated frontal ablation was estimated as 15 to $24 \mathrm{~m}$ from the error ranges assumed in the terminus position and ice-speed measurements.

\section{Results}

\subsection{Ice speed}

The study glaciers showed clear seasonal speed variations (Fig. 3). For example, the ice speed at Tracy Glacier decreased slightly from 2200 to $2100 \mathrm{~m} \mathrm{a}^{-1}$ during the period from March to May 2015 (Fig. 3e). The glacier progressively accelerated to $2500 \mathrm{~m} \mathrm{a}^{-1}$ from late May to early July, followed by gradual deceleration to $2200 \mathrm{~m} \mathrm{a}^{-1}$ from July to September. A similar seasonal speed pattern was observed at Bowdoin Glacier. The ice speed at Bowdoin Glacier was within the range of 300 to $400 \mathrm{~m} \mathrm{a}^{-1}$ during the period from March to May 2015 (Fig. 4e). Ice speed increased from 400 to $600 \mathrm{~m} \mathrm{a}^{-1}$ from late May to early July, and decreased to $350 \mathrm{~m} \mathrm{a}^{-1}$ from July to September. Early summer speedup and late summer slowdown were commonly observed at the other study glaciers (Fig. 4). In general, ice speed showed only minor changes from March to May. Acceleration typically began between late May and early June, followed by the achievement of a peak speed between late June and early July. Ice speed subsequently slowed down from July to September.

The timing of the seasonal speedups and slowdowns is comparable in the study glaciers regardless of size and location. However, the magnitude of summer speedup was significantly different for each glacier. The most significant speedup was observed at Farquhar Glacier, where ice speed increased by more than $300 \mathrm{~m} \mathrm{a}^{-1}$. The magnitude of the speedup at other glaciers ranged between 54 and $278 \mathrm{~m} \mathrm{a}^{-1}$ corresponding to a range between 8 and $226 \%$ increase relative to the speed before the acceleration. Seasonal speed patterns do not always follow the general trend described above. For example, ice speed at Heilprin Glacier showed no significant change from May to July in 2014 (Fig. 3a). Speedup was unclear also at Farquhar Glacier in 2014 (Fig. 3g). 

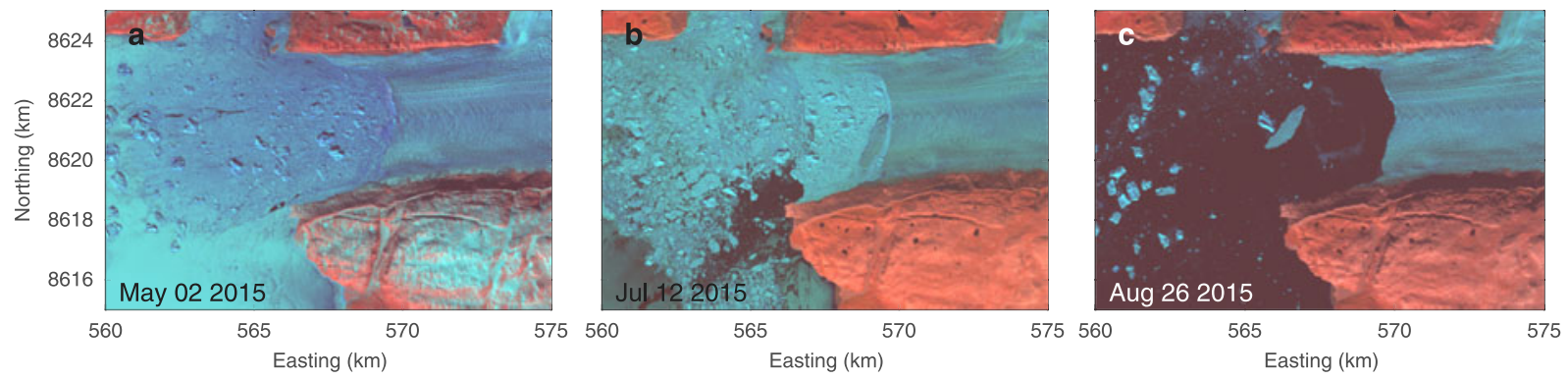

Fig. 2. False color mosaic Landsat images used for categorization of fjord conditions. The examples show conditions in front of Tracy Glacier, which were categorized as (a) rigid, (b) mixed and (c) open sea ice.

\subsection{Terminus position and sea-ice/ice-mélange conditions}

Some of the glaciers showed substantial sudden retreat due to large calving events, typically by more than $100 \mathrm{~m}$ within the interval of satellite images ranging between 2 and 23 days. For example, Heilprin Glacier retreated by $200 \mathrm{~m}$ in June 2014 (Fig. 3a) and in April 2015, and $110 \mathrm{~m}$ in May 2015 (Fig. 3b). Similarly, sporadic major calving events were observed at Tracy (Figs $3 \mathrm{~d}$ to $\mathrm{f}$ ) and Melville Glaciers (Figs $3 \mathrm{j}$ to 1 ). Farquhar (Figs $3 \mathrm{~g}$ to $\mathrm{i}$ ) and Bowdoin Glaciers (Figs $3 \mathrm{~d}$ to $\mathrm{f}$ ) experienced slightly smaller events ( $>50 \mathrm{~m}$ retreat). These sudden retreats were followed by gradual advances lasting for a few months. Some other glaciers showed seasonal variations in the terminus position. For example, Morris Jesup Glacier advanced by $30 \mathrm{~m}$ from May to June and retreated by $130 \mathrm{~m}$ from early July to September in 2014 (Fig. 4j). Verhoeff and Diebitsch Glaciers showed similar frontal variations (Figs $4 \mathrm{~g}$ to $\mathrm{i}$ and $4 \mathrm{~m}$ to o). The change in the trend from advance to retreat occurred typically in June or July.

Sea ice and ice mélange disappeared at most of the glacier fronts in late June to early July (Figs 3,4). The timing of the sea-ice/ice-mélange disappearance was consistent over the three years studied. Fjords opened earlier at Morris Jesup and Diebitsch Glaciers, both situated in the western part of the study area (Figs $4 \mathrm{j}$ to o). Because the fjords of these two glaciers are directly connected to Baffin Bay, sea ice and ice mélange were released earlier in summer that is from mid-April to early June. By contrast, sea ice and ice mélange stayed longer after the onset of melting in Inglefield Bredning. At the fronts of Heilprin, Tracy, Farquhar and Melville Glaciers, mixed conditions lasted for more than two weeks before the glacier front became ice-free. No clear relationship was found between the sea-ice/ ice-mélange conditions and the large calving events observed at these glaciers.

\section{Discussion}

\subsection{Mechanism of seasonal speed variations}

Our data reveal details of seasonal speed variations along the coast of Prudhoe Land. All the study glaciers show speedup in summer. The speedup initiated between late May and early June, speed gradually increased until early July and then it slowed down in the period from July to September. The magnitude of the seasonal speedup was a few $100 \mathrm{~m} \mathrm{a}^{-1}$ which corresponds to $8-226 \%$ increase relative to pre-speedup conditions (Figs 3,4). The observed seasonal speed pattern and magnitude of the speed change are similar to those reported in the Melville Bay region in northwestern Greenland $\left(74.92-76.08^{\circ} \mathrm{N}\right.$ ) (Moon and others, 2014). Thus, the observed seasonal speed pattern appears to be a ubiquitous feature across northwestern Greenland, and the icespeed variations are likely driven by a common mechanism.
To investigate a link between ice speed and atmospheric conditions, the ice-speed time series data were plotted against air temperature averaged over the same period (Fig. 5). This analysis was performed for the data in 2015 because ice speed was measured most frequently for that year out of the study years. The plots demonstrate an influence of air temperature on the speed of the studied glaciers.

For example, ice speed at Heilprin Glacier was fairly stable within $1300-1600 \mathrm{~m} \mathrm{a}^{-1}$ under freezing temperature conditions (arrow 1 in Fig. 5a). This corresponds to a period from March to May (Figs 3b, 3q). About one month after hourly mean temperature exceeded $0^{\circ} \mathrm{C}$ (vertical line in Fig. $3 \mathrm{q}$ ), ice speed began to increase, and further accelerated in the course of the temperature rise. Ice speed and temperature showed a positive correlation until speed reached the maximum in early July (arrow 2 in Fig. 5a). Similar speed-temperature relationships were observed at Tracy, Farquhar, Bowdoin and Verhoeff Glaciers (Figs $5 \mathrm{~b}$ to $\mathrm{c}$ and $5 \mathrm{~g}$ to $\mathrm{h}$ ). The other glaciers showed some unique characteristics, but timing and trend of the speedup were similar to the relationship discussed above, i.e. insignificant speed change when temperatures are below zero, and acceleration to the summer maximum speed as temperatures increase. The relationship implies that the summer speedup was triggered by meltwater production and enhanced as the melt rate increased. Based on these observations, we assume that subglacial water pressure increased due to meltwater penetration into the glacier bed, and the glacier accelerated due to enhanced basal sliding (e.g. Iken, 1972; Andrews and others, 2014; Ryser and others, 2014; Vijay and others, 2019).

After peak speed was attained at Heilprin Glacier, ice motion rapidly decelerated while air temperature remained high (arrow 3 in Fig. 5a). Ice speed remained low until the end of the summer, resulting in a hysteresis loop between ice speed and temperature. A similar drop in ice speed from July to August was observed at all glaciers (Fig. 5). The glaciers decelerated in the middle of summer when meltwater was abundant, which we attribute to the seasonal evolution of the subglacial drainage system. Observations at alpine glaciers have demonstrated that an inefficiently linked cavity system evolves into an efficient conduit drainage system over the course of a melt season (e.g. Iken and Bindschadler, 1986; Fountain and Walder, 1998). After the efficient drainage system is established, subglacial water pressure drops and glacier speed becomes unaffected by the amount of meltwater input to the bed (e.g. Sugiyama and Gudmundsson, 2003; Schoof, 2010). This interpretation is consistent with the speedup mechanism described previously.

At Melville Glacier, ice speed abruptly increased to $>1300 \mathrm{~m} \mathrm{a}^{-1}$ when the air temperature was still below $0^{\circ} \mathrm{C}$ (Fig. 5d). This speedup occurred in May, when the fjord was still covered with sea ice, immediately after the sudden terminus retreat of $\sim 300 \mathrm{~m}$ due to a large calving event (Fig. 3k). Except 

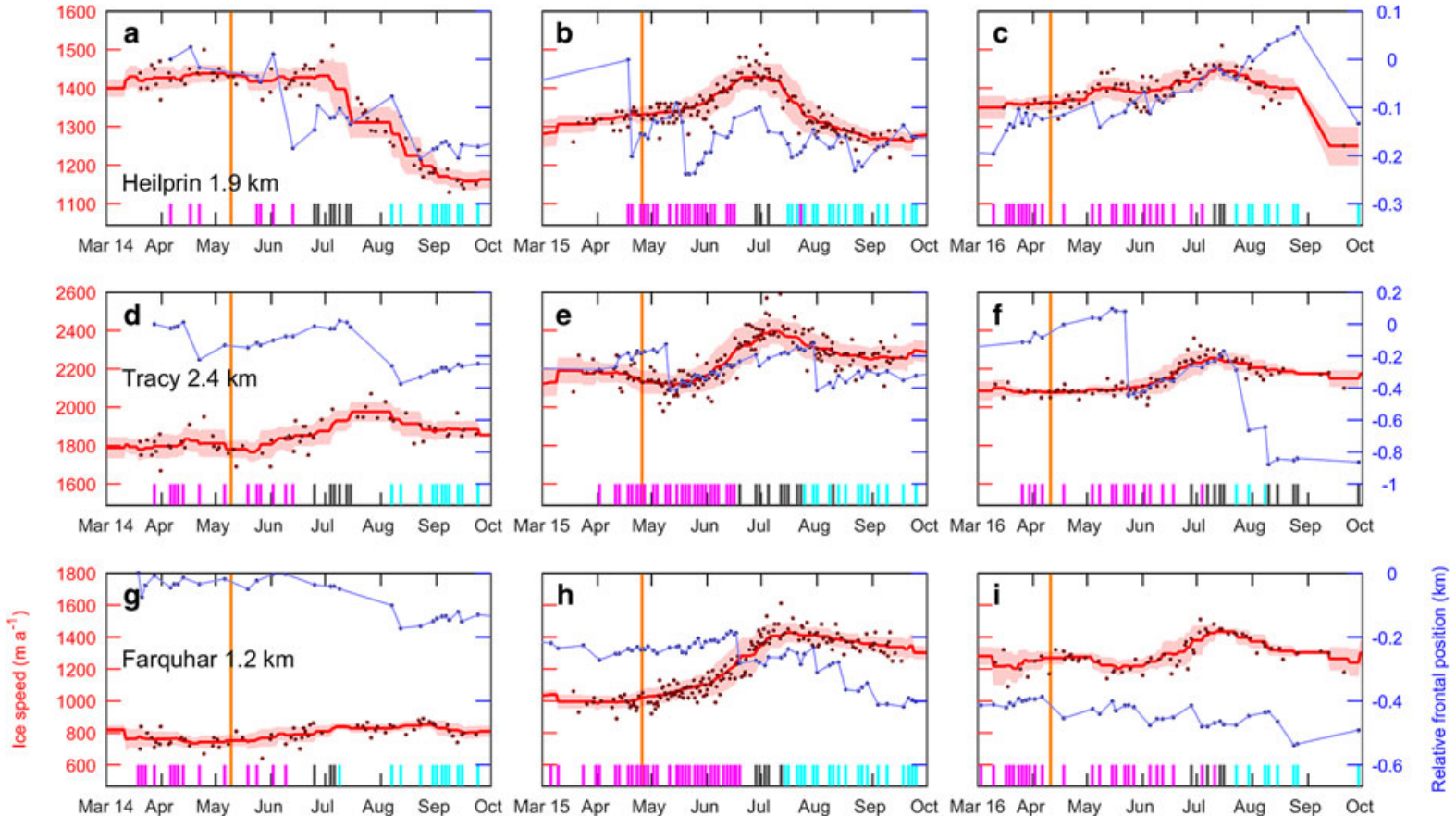

Mar 14 Apr May Jun Jul Aug Sep Oct Mar 15 Apr May Jun Jul Aug Sep Oct Mar 16 Apr May Jun Jul Aug Sep Oc
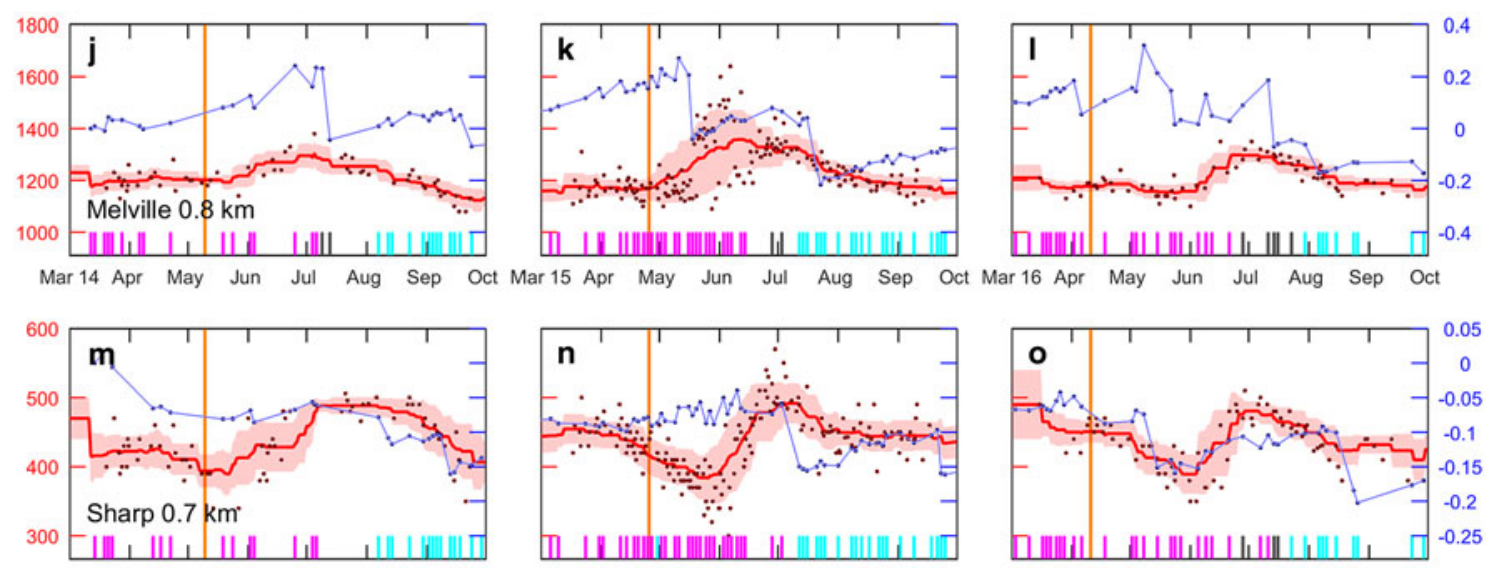

Mar 14 Apr May Jun Jul Aug Sep Oct Mar 15 Apr May Jun Jul Aug Sep Oct Mar 16 Apr May Jun Jul Aug Sep Oct
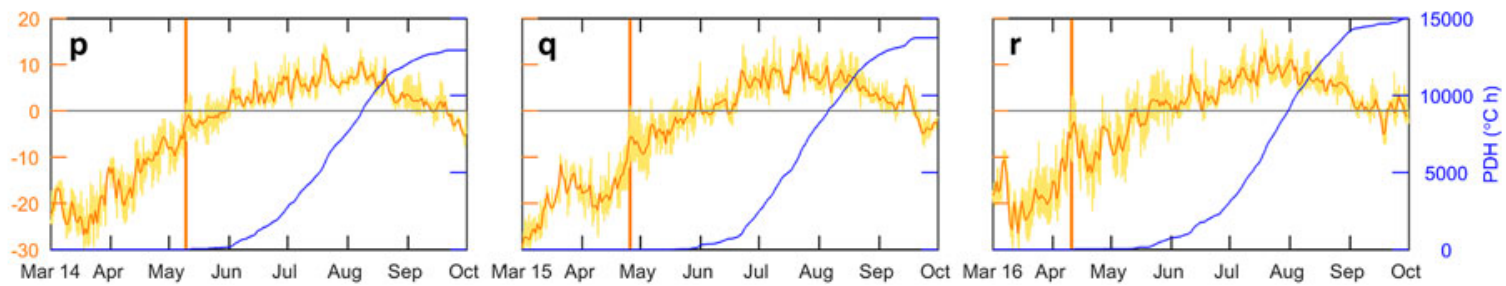

Fig. 3. (a-o) Ice speed (red), terminus position (blue) and sea-ice/ice-mélange conditions (magenta = rigid, gray = mixed and cyan = open) for five study glaciers in the eastern part of the study area. Red lines and associated shaded bands indicate daily mean speed and the std dev., respectively. The distance shown next to the glacier names indicates the location of ice-speed sampling as measured from the 2014 termini. (p-r) Daily (orange) and hourly (yellow) air temperatures, and the sum of the positive degree hours (PDH) (blue) at Qaanaaq Airport. The vertical orange lines show the first day of positive hourly temperature in each year.

for this incident, no clear relationship was observed between frontal variations and glacier dynamics. A sudden retreat of $>200 \mathrm{~m}$ was observed frequently at Heilprin (Figs 3a, b), Tracy (Figs $3 \mathrm{~d}$ to $\mathrm{f}$ ) and other glaciers, but ice speed was unaffected by these events. Seasonal variations in the front position were also not relevant to the change in speed. Morris Jesup, Verhoeff and Diebitsch Glaciers began retreat in June or July, whereas summer speedup of these glaciers began already in May. Therefore, reduction in resistive stress due to terminus retreat (Joughin and others, 2008a, 2014) is not the source of the observed seasonal speed variations. We also found no link between sea-ice/ ice-mélange disappearance from the fjords and the onset of the speedup. Sea ice and ice mélange disappeared typically in early July when summer speedup ceased (Figs 3,4).

Based on the discussion above, we conclude that summer speedup observed at the glaciers in Prudhoe Land was driven by subglacial water pressure which increased due to the meltwater input to the bed. The glaciers decelerated in midsummer when an efficient drainage system developed and water pressure dropped. This result is consistent with a recent study on other glaciers in Greenland reporting the primary influence of surface meltwater production and associated subglacial hydraulic conditions on a seasonal ice-speed change (Vijay and others, 2019). The effect of the glacier front position on the ice speed is limited, although 

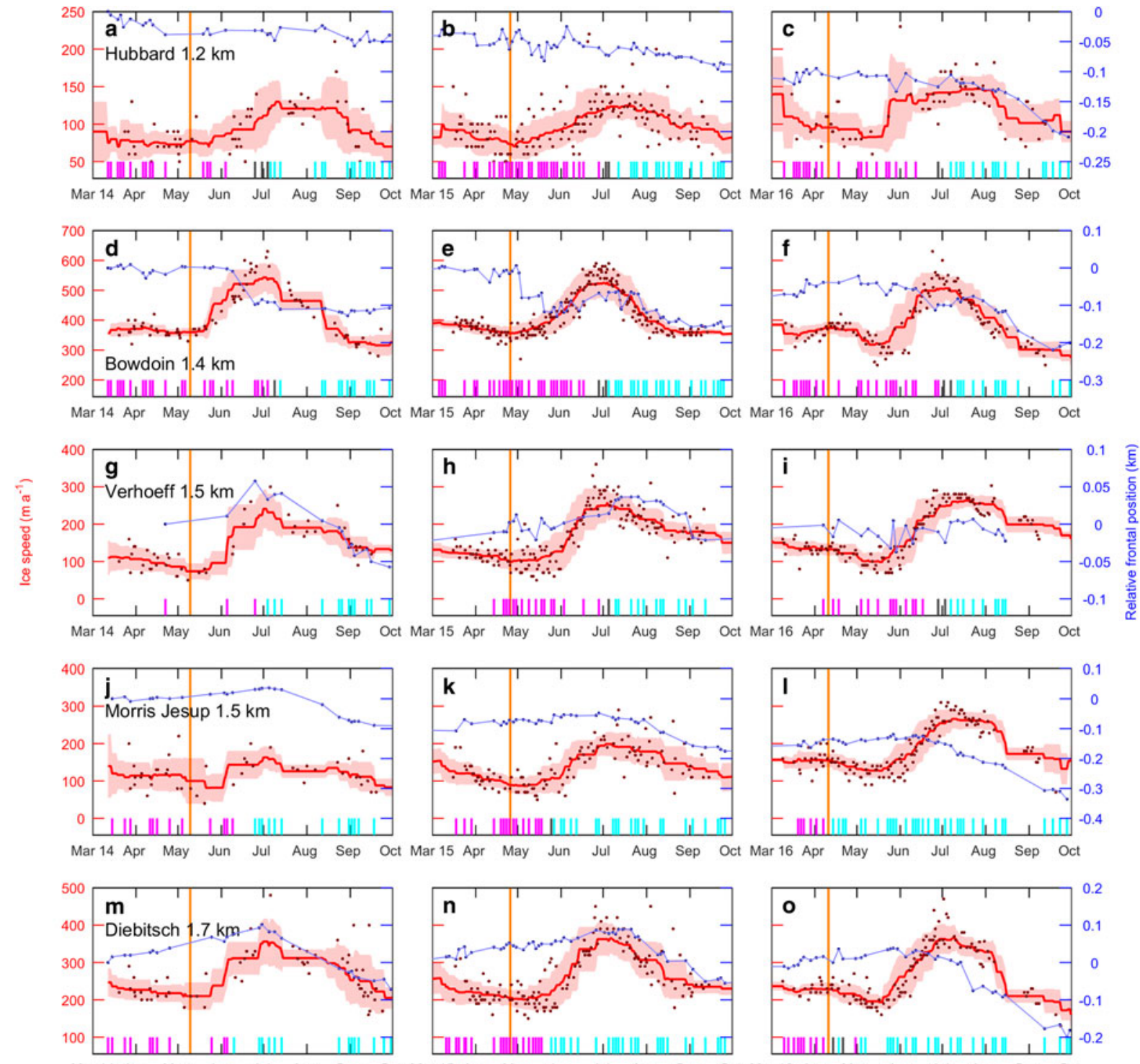

Mar 14 Apr May Jun Jul Aug Sep Oct Mar 15 Apr May Jun Jul Aug Sep Oct Mar 16 Apr May Jun Jul Aug Sep Oct

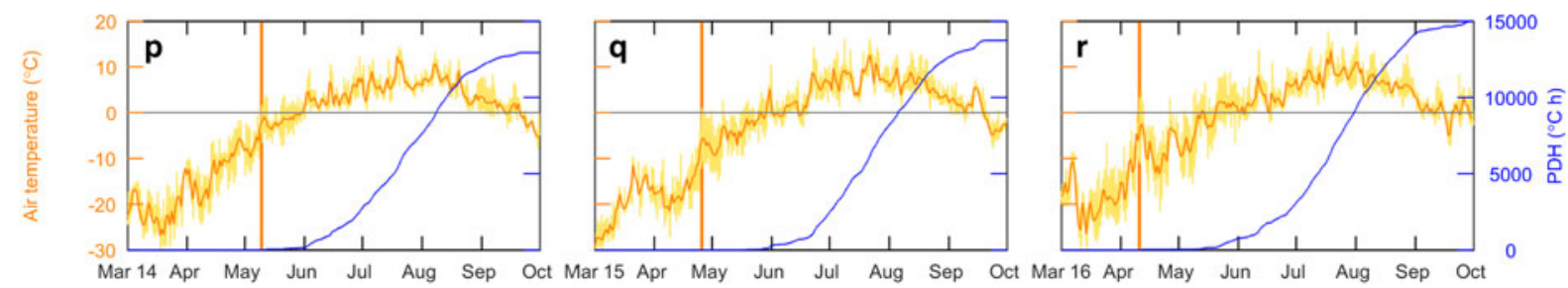

Fig. 4. (a-o) Ice speed (red), terminus position (blue) and sea-ice/ice-mélange conditions (magenta = rigid, gray = mixed and cyan = open) for five study glaciers in the western part of the study area. Red lines and associated shaded bands indicate daily mean speed and the std dev., respectively. The distance shown next to the glacier names indicates the location of ice-speed sampling as measured from the 2014 termini. (p-r) Daily (orange) and hourly (yellow) air temperatures, and the sum of the PDH (blue) at Qaanaaq Airport. The vertical orange lines show the first day of positive hourly temperature in each year.

sudden retreat due to a large calving event sometimes triggered glacier acceleration.

\subsection{Contribution of summer speedup to glacier motion}

As demonstrated in recent studies (Moon and others, 2014, 2015), seasonal speed patterns are crucial for quantifying the annual discharge of marine-terminating outlet glaciers in Greenland. To investigate the relative importance of the observed summer speedup in longer-term ice discharge, we quantified the contribution of summer speedup to annual ice motion. We define the magnitude of summer speedup as the difference between summer speed (June-August) and 'base speed' defined by the mean over the rest of the year (September-May of the following year). In other words, summer speedup refers to the additional displacement that occurs on top of the base flow. The magnitude of the summer speedups was compared with annual ice motion, using data from September 2014 to August 2016 (Fig. 6).

The contribution of the summer speedup to annual motion of fast-flowing Heilprin, Tracy, Farquhar and Melville Glaciers, which flow at a rate $>1000 \mathrm{~m} \mathrm{a}^{-1}$, was within the range of 24-62 $\mathrm{m} \mathrm{a}^{-1}$ (2-5\%) (Fig. 6a). Summer speedup contribution of the other six glaciers ranged from 2 to $23 \mathrm{~m} \mathrm{a}^{-1}(0.5-13 \%)$ 

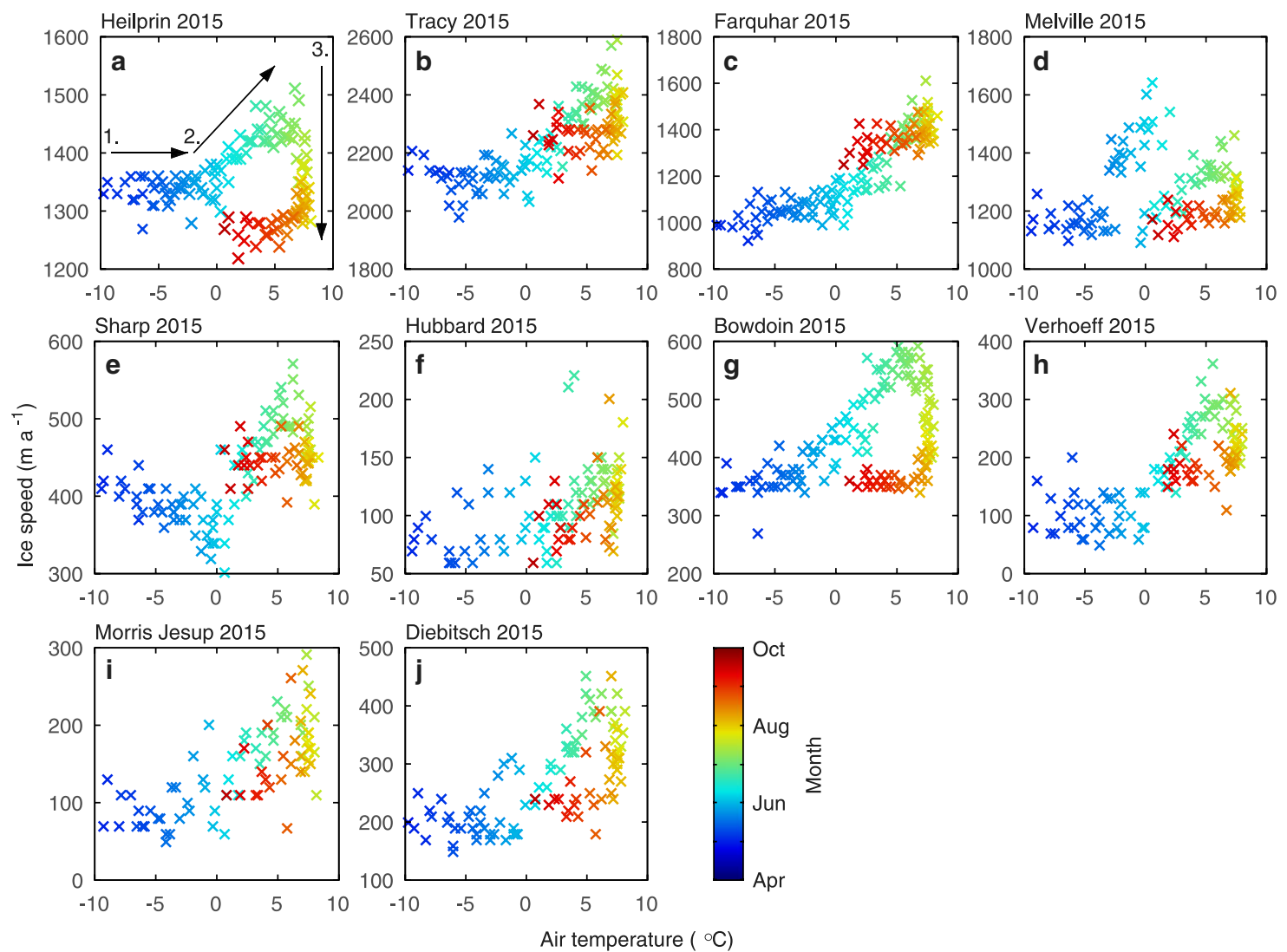

Fig. 5. Scatter plots of ice speed and air temperature at Qaanaaq Airport averaged over each ice-speed measurement period. The data covers a period from April to October 2015.
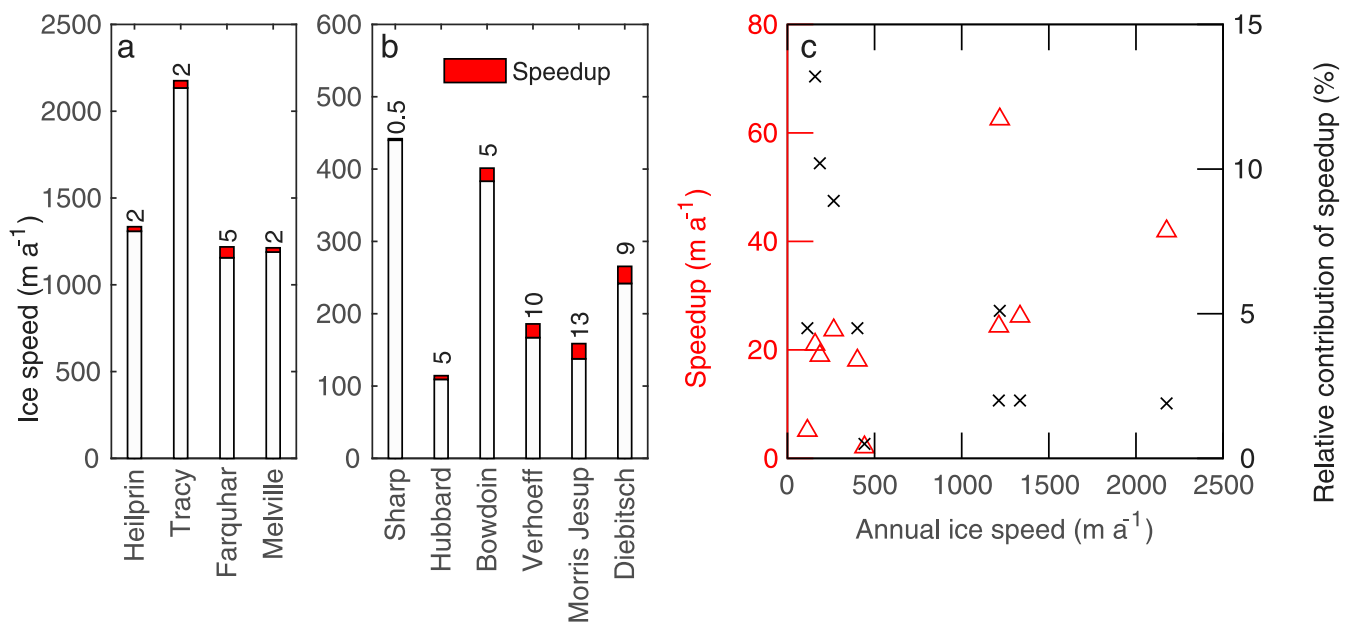

Fig. 6. The contribution of summer speedup (June-August) to mean ice speed from September 2014 to August 2016 for (a) Heilprin, Tracy, Farquhar and Melville Glaciers and (b) Sharp, Hubbard, Bowdoin, Verhoeff, Morris Jesup and Diebitsch Glaciers. The numbers indicate the relative contributions of the summer speedup in \%. (c) Scatter plots of the summer speedup and its relative contribution vs the mean ice speed.

(Fig. 6b). Summer increase in total ice discharge from the Greenland ice sheet is reported as $\sim 6 \%$ of the annual mean (King and others, 2018), which implies a 2-3\% contribution of summer speedup to annual ice discharge. This estimate is consistent with our results obtained for fast-flowing glaciers. Our results demonstrate that the impact of summer speedup on annual ice motion was greater at relatively slow-flowing glaciers, whereas larger magnitude of speedup was observed at fast-flowing glaciers (Fig. 6c). Seasonal speed variation was particularly important at Verhoeff and Morris Jesup Glaciers, where summer speedup accounted for more than $10 \%$ of annual ice motion. The numbers obtained for the slow-flowing glacier are similar to those reported for a land-terminating glacier in western Greenland (6-14\%) (Bartholomew and others, 2010). In the previous studies, the magnitude of summer speedup of marine-terminating glaciers was greater near the terminus than inland (Sole and others, 2011; Joughin and others, 2014). Therefore, it is important to understand seasonal speed patterns near the glacier termini to accurately quantify annual ice discharge from marine-terminating glaciers. 


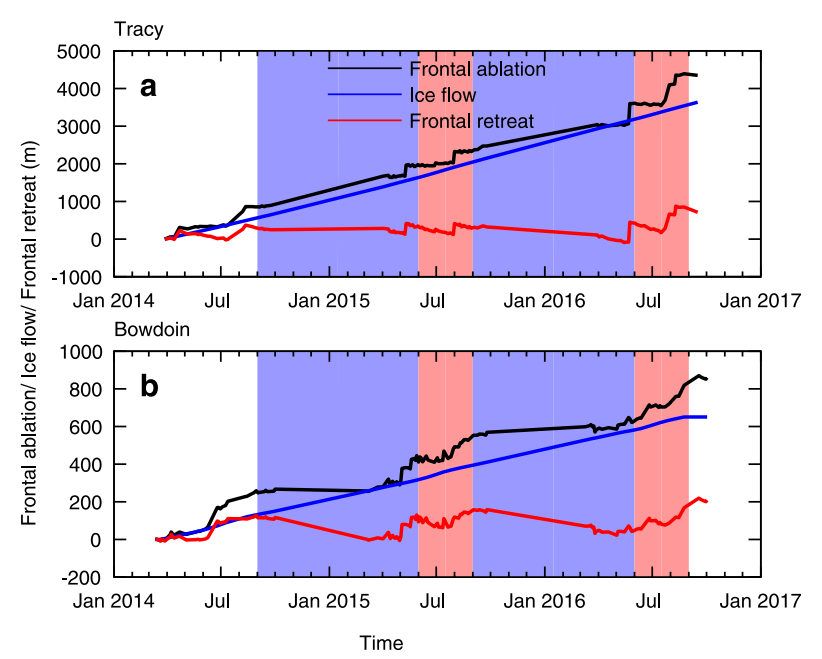

Fig. 7. Cumulative ice motion near the glacier front (blue), ice front displacement (positive number shows retreat) (red) and cumulative frontal ablation obtained as the sum of the ice motion and the frontal displacement (green) from 2014 to 2016 for (a) Tracy and (b) Bowdoin Glacier.

\subsection{Seasonal variations in the frontal ablation}

The high-frequency ice speed and terminus position data enabled us to quantify temporal variations in frontal ablation. Figure 7 shows cumulative forward ice motion near the glacier front, terminus position (positive number shows retreat) and cumulative frontal ablation of Tracy and Bowdoin Glaciers. The frontal ablation of Tracy Glacier occurred at a nearly constant rate throughout the study period, except for several calving events represented by the sudden retreat in May and July 2015, and May 2016 (Fig. 7a). These large calving events occurred irrespective of sea-ice/ice-mélange conditions (Figs 3e, f). Frontal ablation at Heilprin and Farquhar Glaciers showed seasonal patterns similar to that at Tracy Glacier (Figs s2a, b). Large calving events are more frequent during summer periods, but the glacier front steadily loses ice by frontal ablation throughout the year. In contrast to these three glaciers, frontal ablation at Bowdoin Glacier was greater in summer than during the other period (Fig. 7b). Ablation during a period from June to August (25\% period of a year) accounted for $59 \%$ of the total ablation which occurred from September 2014 to August 2016. This seasonality in the frontal ablation caused seasonal variations in the terminus position, i.e. retreat in summer and advance during the rest of the year (Fig. 7b). Forward ice motion was greater in summer, but enhanced frontal ablation was the dominant factor affecting change in the terminus position. Similar trends in the frontal ablation were observed in Melville, Verhoeff, Morris Jesup and Diebitsch Glaciers (Figs s2c, f, g and h).

The contribution of the summer frontal ablation (JuneAugust) to the total ablation varied for each glacier (Fig. 8). At Heilprin Glacier, summer ablation accounts for $22 \%$ $\left(140 \mathrm{~m} \mathrm{a}^{-1}\right)$ of the ablation that occurred from September 2014 to August 2016, indicating a near-uniform distribution over the period of a year. The contribution was slightly greater at Tracy, Farquhar, Melville, Sharp and Hubbard Glaciers, ranging from 33 to $41 \%\left(60-570 \mathrm{~m} \mathrm{a}^{-1}\right)$. Around the half of the annual frontal ablation occurred during summer at Bowdoin, Verhoeff, Morris Jesup and Diebitsch Glaciers $\left(80-180 \mathrm{~m} \mathrm{a}^{-1}\right.$ ) (Figs 8a, b). Summer frontal ablation is generally correlated with annual ablation, but its relative contribution decreases as annual ablation increases (Fig. 8c).

The first group, glaciers with year-round distributed frontal ablation, was characterized by fast ice flow and large-glacier size. We assume that the influence of summer speedup and sea-ice/ice-mélange melting on calving was less significant at this type of glacier. This is because the relative contribution of summer speedup to annual ice motion is small at these glaciers (Fig. 6). It is also likely that the buttressing effect of sea ice and ice mélange was insufficient to stabilize the fast-flowing glacier front. The greater contribution of summer frontal ablation at other glaciers can be explained by calving enhanced by speedup and the loss of sea ice/ice mélange, which play a more important role in the calving of smaller and slow-flowing glaciers.

We also suspect an influence of submarine melting on the seasonal variations in the frontal ablation. Fjord depth at the glacier front is important for submarine melting because it affects the intrusion of warm Atlantic water (AW) (Porter and others, 2014; Rignot and others, 2016). According to the glacier bed elevation measured in 2014 (CReSIS, 2016), the fjords are deeper than $300 \mathrm{~m}$ below sea level at the front of Heilprin, Tracy and Farquhar Glaciers. AW intrudes into such deep fjords and provides heat for submarine melting throughout the year (Porter and others, 2014). In contrast to these large glaciers, Bowdoin, Verhoeff, Morris Jesup and Diebitsch Glaciers flow into fjords shallower than $200 \mathrm{~m}$ (Sugiyama and others, 2015; OMG mission, 2016). A submarine melt rate increases in summer because of
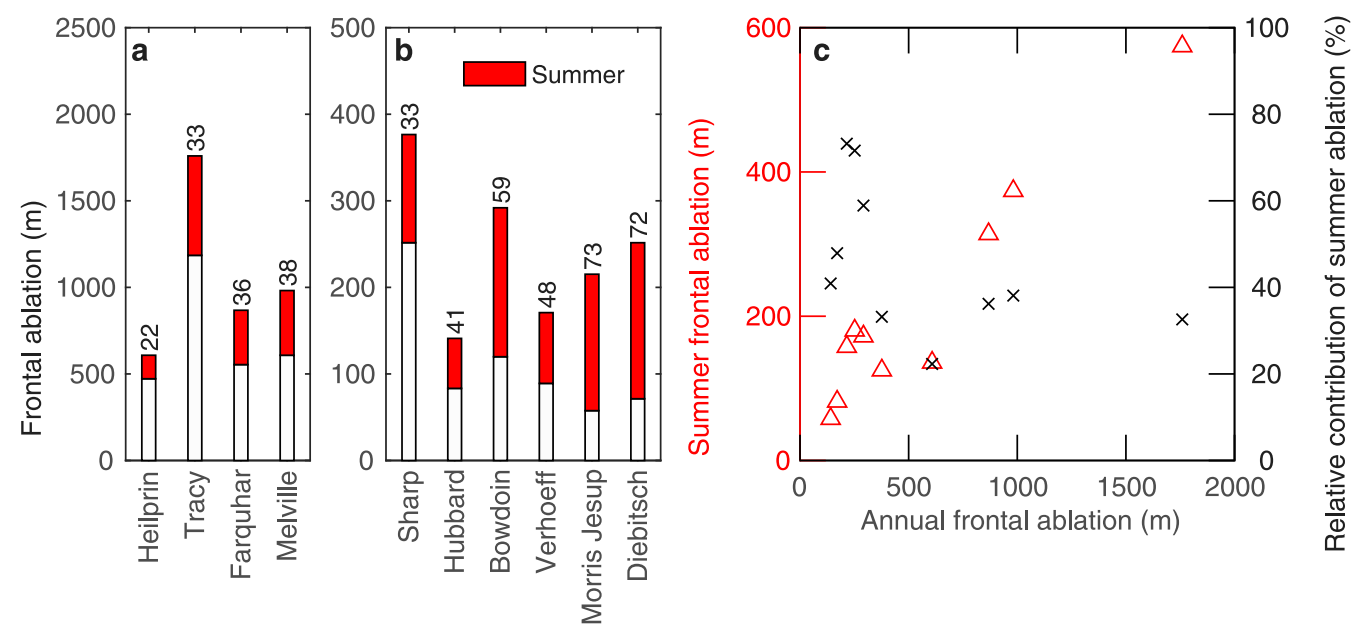

Fig. 8. Frontal ablation rate for (a) Heilprin, Tracy, Farquhar and Melville Glaciers and (b) Sharp, Hubbard, Bowdoin, Verhoeff, Morris Jesup and Diebitsch Glaciers. The numbers indicate the relative contributions of the summer frontal ablation (red) to the annual ablation in \%. The data are the mean values over a period between September 2014 and September 2016. (c) Scatter plots of the summer frontal ablation and its relative contribution vs the annual frontal ablation rate. 
fjord circulation driven by subglacial meltwater discharge (e.g. Sciascia and others, 2013). We speculate that the contribution of summer submarine melting is more significant at these glaciers because warm AW is not available in winter. Submarine melting increases in summer and enhances calving (Fried and others, 2015; Rignot and others, 2015), which results in greater seasonal variations in frontal ablation.

\section{Conclusions}

We studied ice-speed variations of 10 marine-terminating outlet glaciers along the coast of Prudhoe Land in northwestern Greenland. During the study period from 2014 to 2016, the glaciers showed a common seasonal speed pattern: speedup began between late May and early June, increased gradually until it reached its peak value between late June and early July, and subsequently slowed down from July to September. The magnitude of the speedup was within the range of 54 to $278 \mathrm{~m} \mathrm{a}^{-1}(8-226 \%)$. This seasonal speed pattern was similar to the one reported in the nearby Melville Bay region in northwest Greenland (74.92$\left.76.08^{\circ} \mathrm{N}\right)($ Moon and others, 2014), suggesting that the observed seasonal speed pattern is commonly distributed over all of northwestern Greenland.

Observed summer speedups began approximately when hourly air temperatures exceeded $0^{\circ} \mathrm{C}$ in early summer. Ice speed decelerated in midsummer when air temperature still remained at the highest level. The influence of frontal retreat and sea-ice/ ice-mélange conditions was insignificant. Based on these observations, we conclude that summer speedup was driven by subglacial water pressure which increased due to the meltwater input to the glacier bed, and the glacier decelerated when the pressure dropped through the development of an efficient subglacial drainage system. The contribution of summer speedup to annual ice motion ranged from 2 to $62 \mathrm{~m} \mathrm{a}^{-1}(0.5-13 \%)$, and the relative contribution was greater at slow-flowing glaciers.

Frontal ablation of the study glaciers showed seasonal variations as well. Greater ablation was observed in the summer period (June-August) and the seasonality is more enhanced in relatively small and slow-flowing glaciers. For example, more than a half of the annual frontal ablation occurred during the summer period at Bowdoin, Verhoeff, Morris Jesup and Diebitsch Glaciers. These glaciers showed clear seasonal variations in the front position: advance from March to June/July and retreat from July to September. The frontal variations were dominated by the seasonal variations in the frontal ablation rather than by ice-speed variations, suggesting the importance of ocean influence on calving and submarine melting. Observed seasonal front variations were critically controlled by summer frontal ablation particularly at relatively small slow-flowing glaciers. At the front of these glaciers, calving is enhanced by speedup and sea-ice/ice-mélange weakening during the summer period.

Supplementary material. The supplementary material for this article can be found at https://doi.org/10.1017/jog.2019.81.

Acknowledgements. We thank Jason Amundson and an anonymous referee for constructive review comments. The paper was handled by the Scientific Editor Shad O'Neel and commented by the Chief Editor Hester Jiskoot. The Landsat images were downloaded from the United States Geological Survey Earth Explorer (http://earthexplorer.usgs.gov/). The dataset of air temperature was downloaded from the National Oceanic and Atmospheric Administration's National Centers for Environmental Information (https:// www.ncdc.noaa.gov/). English text was corrected by Susan Braun-Clarke. This study was funded by MEXT Japan (Japanese Ministry of Education, Culture, Sports, Science and Technology) through the Arctic Challenge for Sustainability (ArCS) Project.
Author contribution. DS processed satellite data, analyzed the results and wrote the paper. SS contributed to the interpretation of the results and writing.

\section{References}

Amundson JM and 5 others (2010) Ice mélange dynamics and implications for terminus stability, Jakobshavn Isbræ, Greenland. Journal of Geophysical Research 115, F01005. doi: 10.1029/2009JF001405.

Andrews LC and 7 others (2014) Direct observations of evolving subglacial drainage beneath the Greenland ice sheet. Nature 514(7520), 80-83. doi: 10.1038/nature13796

Bartholomew I and 5 others (2010) Seasonal evolution of subglacial drainage and acceleration in a Greenland outlet glacier. Nature Geoscience 3(6), 408411. doi: 10.1038/ngeo863.

Carr JR, Stokes CR and Vieli A (2013) Recent progress in understanding marine-terminating Arctic outlet glacier response to climatic and oceanic forcing: twenty years of rapid change. Progress in Physical Geography 37 (4), 436-467. doi: 10.1177/0309133313483163.

CReSIS (2016) Radar Depth Sounder L2 Data, Lawrence, Kansas, USA, Digital Media. Available at http://data.cresis.ku.edu/.

Fountain AG and Walder JS (1998) Water flow through temperate glaciers. Reviews of Geophysics 36(3), 299-328. doi: 10.1029/97RG03579.

Fried MJ and 8 others (2015) Distributed subglacial discharge drives significant submarine melt at a Greenland tidewater glacier. Geophysical Research Letters 42, 9328-9336. doi: 10.1002/2015GL065806.

Heid T and Kääb A (2012) Evaluation of existing image matching methods for deriving glacier surface displacements globally from optical satellite imagery. Remote Sensing of Environment 118, 339-355. doi: 10.1016/j.rse. 2011.11.024.

Howat IM, Box JE, Ahn Y, Herrington A and McFadden EM (2010) Seasonal variability in the dynamics of marine-terminating outlet glaciers in Greenland. Journal of Glaciology 56(198), 601-613. doi: 10.3189/ 002214310793146232.

Howat IM, Joughin I, Fahnestock M, Smith BE and Scambos TA (2008) Synchronous retreat and acceleration of southeast Greenland outlet glaciers 2000-06: ice dynamics and coupling to climate. Journal of Glaciology 54 (187), 646-660. doi: 10.3189/002214308786570908.

Iken A (1972) Measurement of water pressure in moulins as part of a movement study of the White Glacier, Axel Heiberg Island, Northwest Territories, Canada. Journal of Glaciology 77, 53-58. doi: 10.3189/S0022143000022486.

Iken A and Bindschadler RA (1986) Combined measurements of subglacial water pressure and surface velocity of Findelengletscher, Switzerland: conclusions about drainage system and sliding mechanism. Journal of Glaciology 32, 101-119. doi: 10.3189/S0022143000006936.

Joughin I and 7 others (2008a) Continued evolution of Jakobshavn Isbrae following its rapid speedup. Journal of Geophysical Research 113, F04006. doi: $10.1029 / 2008$ JF001023.

Joughin I and 5 others (2008b) Seasonal speedup along the western flank of the Greenland Ice Sheet. Science 320(5877), 781-783. doi: 10.1126/science. 1153288 .

Joughin I, Smith BE, Shean DE and Floricioiu D (2014) Brief communication: further summer speedup of Jakobshavn Isbræ. Cryosphere 8(1), 209214. doi: $10.5194 /$ tc-8-209-2014.

King MD and 6 others (2018) Seasonal to decadal variability in ice discharge from the Greenland ice sheet. Cryosphere 12, 3813-3825. doi: 10.5194/ tc-12-3813-2018.

Lemos A, Shepherd A, McMillan M and Hogg AE (2018) Seasonal variations in the flow of land-terminating glaciers in Central-West Greenland using sentinel-1 imagery. Remote Sensing 10, 1878. doi: 10.3390/rs10121878.

Mankoff KD and 10 others (2019) Greenland ice sheet solid ice discharge from 1986 through 2017. Earth System Science Data 11, 769-786. doi: 10.5194/essd-11-769-2019.

McNabb RW and Hock R (2014) Alaska tidewater glacier terminus positions, 1948-2012. Journal of Geophysical Research. Earth Surface 119. doi: 10.1002/2013JF002915.

Moon T and 6 others (2014) Distinct patterns of seasonal Greenland glacier velocity. Geophysical Research Letters 41. doi: 10.1002/2014GL061836.

Moon T and Joughin I (2008) Changes in ice front position on Greenland's outlet glaciers from 1992 to 2007. Journal of Geophysical Research 113, F02022. doi: 10.1029/2007JF000927.

Moon T, Joughin I and Smith B (2015) Seasonal to multiyear variability of glacier surface velocity, terminus position, and sea ice/ice mélange in 
northwest Greenland. Journal of Geophysical Research. Earth Surface 120, 818-833. doi: 10.1002/2015JF003494.

Moon T, Joughin I, Smith B and Howat I (2012) 21st-century evolution of Greenland outlet glacier velocities. Science 336(6081), 576-578. doi: 10.1126/science.1219985.

Nick FM, Vieli A, Howat IM and Joughin I (2009) Large-scale changes in Greenland outlet glacier dynamics triggered at the terminus. Nature Geoscience 2(2), 110-114. doi: 10.1038/ngeo394.

OMG Mission (2016) Bathymetry (sea floor depth) data from the ship-based bathymetry survey. Ver. 0.1. OMG SDS, CA, USA. Available at https://doi. org/10.5067/OMGEV-BTYSS (Accessed 2 February 2018).

Pimentel S and 7 others (2017) Modelling intra-annual dynamics of a major marine-terminating Arctic glacier. Annals of Glaciology 58(74), 118-130. doi: 10.1017/aog.2017.23.

Porter DF and 6 others (2014) Bathymetric control of tidewater glacier mass loss in northwest Greenland. Earth and Planetary Science Letters 401, 40-46. doi: 10.1016/j.epsl.2014.05.058.

Rignot E and 9 others (2016) Bathymetry data reveal glaciers vulnerable to ice-ocean interaction in Uummannaq and Vaigat glacial fjords, west Greenland. Geophysical Research Letters 43. doi: 10.1002/2016GL067832.

Rignot E, Fenty I, Xu Y, Cai C and Kemp C (2015) Undercutting of marineterminating glaciers in West Greenland. Geophysical Research Letters 42, 5909-5917. doi: 10.1002/2015GL064236.

Rignot E and Kanagaratnam P (2006) Changes in the velocity structure of the Greenland Ice Sheet. Science 311, 986-990. doi: 10.1126/science.1121381.

Ryser C and 7 others (2014) Caterpillar-like ice motion in the ablation zone of the Greenland ice sheet. Journal of Geophysical Research. Earth Surface, 119, 2258-2271. doi: 10.1002/2013JF003067.

Sakakibara D and Sugiyama S (2014) Ice-front variations and speed changes of calving glaciers in the Southern Patagonia Icefield from 1984 to 2011. Journal of Geophysical Research. Earth Surface 119, 2541-2554. doi: 10. 1002/2014JF003148.

Sakakibara D and Sugiyama S (2018) Ice front and flow speed variations of marine-terminating outlet glaciers along the coast of Prudhoe Land, northwestern Greenland. Journal of Glaciology 64(244), 300-310. doi: 10. 1017/jog.2018.20.

Scambos TA, Dutkiewicz MJ, Wilson JC and Bindschadler RA (1992) Application of image cross-correlation to the measurement of glacier ice speed using satellite image data. Remote Sensing of Environment 42, 177186. doi: 10.1016/0034-4257(92)90101-O.

Schoof C (2010) Ice-sheet acceleration driven by melt supply variability. Nature 468(7325), 803-806. doi: 10.1038/nature09618.

Sciascia R, Straneo F, Cenedese C and Heimbach P (2013) Seasonal variability of submarine melt rate and circulation in an East Greenland fjord. Journal of Geophysical Research. Oceans 118, 2492-2506. doi: 10.1002/jgrc.20142.

Sole AJ and 6 others (2011) Seasonal speedup of a Greenland marineterminating outlet glacier forced by surface melt-induced changes in subglacial hydrology. Journal of Geophysical Research 116, F03014. doi: 10.1029/ 2010JF001948.

Sugiyama S and Gudmundsson GH (2003) Diurnal variations in vertical strain observed in a temperate valley glacier. Geophysical Research Letters 30(2), 1090. doi: 10.1029/2002GL016160.

Sugiyama S, Sakakibara D, Tsutaki S, Maruyama M and Sawagaki T (2015) Glacier dynamics near the calving front of Bowdoin Glacier, northwestern Greenland. Journal of Glaciology 61(226), 223-232. doi: 10.3189/ 2015JoG14J127.

Sundal AV and 5 others (2011) Melt-induced speed-up of Greenland ice sheet offset by efficient subglacial drainage. Nature 469, 521-524. doi: 10.1038/ nature09740.

Tsutaki S, Sugiyama S, Sakakibara D and Sawagaki T (2016) Surface elevation changes during 2007-13 on Bowdoin and Tugto Glaciers, northwestern Greenland. Journal of Glaciology 62(236), 1083-1092. doi: 10.1017/jog.2016.106.

van den Broeke MR and 8 others (2016) On the recent contribution of the Greenland ice sheet to sea level change. Cryosphere 10(5), 1933-1946. doi: 10.5194/tc-10-1933-2016.

Vijay S and 5 others (2019) Resolving seasonal ice velocity of 45 Greenlandic glaciers with very high temporal details. Geophysical Research Letters 46, 1485-1495. doi: 10.1029/2018GL081503. 